\title{
CD36 overexpression: a possible etiopathogenic mechanism of atherosclerosis in patients with prediabetes and diabetes
}

\author{
M. D. Lopez-Carmona', M. C. Plaza-Seron², A. Vargas-Candela' , F. J. Tinahones ${ }^{3,4}$, R. Gomez-Huelgas 1,4 \\ and M. R. Bernal-Lopez $z^{1,4^{*}}$
}

\begin{abstract}
Rationale: CD36 is a scavenger receptor located on monocytes which is involved in foam cell transformation.

Aim: To evaluate CD36 expression under different glycemic states in both healthy subjects and in atherosclerotic patients.

Subjects and methods: In order to evaluate the possible effects of hyperglycemia on CD36 expression in healthy subjects, an in vitro experiment was carried out using monocyte in three different conditions: extreme hyperglycemia $(H G)$, euglycemia $(E G)$ and in the absence of glucose. On the other hand, three groups of atherosclerotic patients were evaluated according to their glycemic conditions: normoglycemic (NG), prediabetic (preDM) and diabetic (DM) patients. CD36 expression (mRNA, non-glycated and glycated protein) was analyzed in monocytes.

Results: CD36 mRNA expression in the in vitro experiment peaked at 4 and $24 \mathrm{~h}$ under $\mathrm{HG}$ conditions. No differences in mRNA levels were found in the EG and control group. The level of non-glycated proteins was higher in HG and EG conditions compared with control group. Glycated protein expression was inhibited by glucose in a sustained manner. In atherosclerotic patients, a significant association was observed when comparing glycated CD36 protein expression in DM with NG patients $(p=0.03)$. No significant differences were found in mRNA and non-glycated CD36 expression in these patients. Moreover, BMI, insulin, weight and treatment were shown to be related to CD36 expression (mRNA, non-glycated and glycated protein levels, depending of the case) in atherosclerotic patients.
\end{abstract}

Conclusions: Hyperglycemia is an important modulator of CD36 mRNA and non-glycated protein expression in vitro, increasing de novo synthesis in healthy subjects. In atherosclerotic patients, there are progressive increases in CD36 receptors, which may be due to a post-translational stimulus.

Keywords: Atherosclerosis, Type 2 diabetes, CD36 receptor, Human clinical, Monocytes

\section{Background}

Cardiovascular diseases are very prevalent pathologies in the general population. They affect the majority of adults over 60 years of age and are the main cause of death in developed countries. Although efforts have been made in recent years to reduce this cause of death, the rate of

\footnotetext{
*Correspondence: robelopajiju@yahoo.es

${ }^{1}$ Internal Medicine Department, Biomedical Institute of Malaga (IBIMA), Regional University Hospital of Malaga (Carlos Haya Hospital), Avda. Hospital Civil s/n, 29009 Malaga, Spain

Full list of author information is available at the end of the article
}

reduction has slowed in recent decades [1,2]. Epidemiological studies have identified different cardiovascular risk factors such as age, gender, obesity, family history of cardiovascular disease, smoking habits, dyslipidemia, hypertension and diabetes mellitus (DM).

In diabetic patients, atherosclerosis is the most frequent cardiovascular disease. It develops at a young age and in an extensive manner. In fact, premature vascular disease is the main cause of morbidity and mortality among diabetic patients [3]. Hyperinsulinemia can promote monocytes to produce foam cells and contribute to the development of atherosclerosis in diabetic 
patients [4]. Moreover, the increased prevalence of atherosclerotic disease is not explained by the presence of other cardiovascular risk factors in prediabetic (preDM) patients [5].

The pathophysiological mechanisms involved in the increased risk of cardiovascular disease are not entirely clear. The development of atherosclerotic damage has been attributed to lipoprotein accumulation in the intima layer, especially an accumulation of low-density lipoproteins (LDL) [6]. After crossing the endothelium, these lipoproteins are modified [7, 8] and taken up by macrophages and smooth muscle cells [9] through two principal mechanisms: by specific LDL receptors (LDL-R) $[10,11]$ and by scavenger receptors [12].

CD36 is a scavenger receptor with a high affinity for oxidized LDL (oxLDL) [13]. It is expressed by various types of cells such as platelets, macrophages, adipocytes and smooth muscle cells. It binds oxLDL with a high affinity and, in monocytes-macrophages, CD36 is responsible for the transformation into foam cells in $60-70 \%$ of cases $[14,15]$. This receptor is synthesized as non-glycated protein (55 KD). It then undergoes various cytoplasmatic post-translational changes to transform it into a glycated protein $(88 \mathrm{KD})$ that is anchored to the cellular surface. CD36 has been described as having a pathogenic effect during atherosclerotic vascular disease due the direct relationship between this pathology and the expression of the receptor. In fact, overexpression of this receptor could be one of the mechanisms behind accelerated atherosclerosis in diabetic patients [16]. However, some evidence has shown that this expression could be affected by a change in hyperglycemic conditions [17]. Moreover, recent studies have shown that higher levels of this marker in the blood can be used as potential marker of cardiovascular disease $[18,19]$.

The aim of this study was to analyze CD36 expression in peripheral blood monocytes in healthy subjects in different cell culture conditions: extreme hyperglycemia (HG), euglycemia (EG) or without glucose (saline solution) (control group). Furthermore, we evaluated whether different CD36 expression levels were associated with different degrees of glucose metabolism alteration in normoglycemic (NG), prediabetic (preDM) and diabetic (DM) patients.

\section{Patients and methods}

This experiment consisted of two parts. The first part was a preliminary in vitro study with the objective of analyzing the influence of hyperglycemia on CD36 receptor expression. The second part was a study carried out in patients diagnosed with severe atherosclerosis, in which we measured the CD36 expression in different states of carbohydrate metabolism.

\section{In vitro experiments in healthy subjects}

Peripheral blood mononuclear cells (PBMC) were isolated from three bags of red blood cell concentrate from healthy donors with $\mathrm{AB} \mathrm{Rh}+$ blood type. Cells were separated by standard density gradient centrifugation with Ficoll (Sigma-Aldrich, St. Louis, MO, USA) (400g, for $40 \mathrm{~min}$, at room temperature $\left(22^{\circ} \mathrm{C}\right)$ without stopping). One million monocytes per well were grown over $48 \mathrm{~h}$ in monolayer cultures on plates using Gibco ${ }^{\circledR}$ RPMI 1640 cell culture medium (Gibco, Invitrogen Co., Carlsbad, CA, USA) supplemented with glutamine.

To compare the effects of hyperglycemia on CD36 mRNA, non-glycated and glycated protein expression, PBMC were exposed to different glucose (Sigma-Aldrich) concentrations $(5.5,26 \mathrm{mM}$ or without glucose in a $0.9 \%$ saline solution), to simulate euglycemic (EG), hyperglycemic (HG) or control conditions, respectively. These glucose concentrations were determined in relation to normal plasma glycemic levels $(5.5 \mathrm{mM}=95 \mathrm{mg} / \mathrm{dL})$ and in relation to very high plasma glycemic levels, in the postprandial situation $(26 \mathrm{mM}=498 \mathrm{mg} / \mathrm{dL})$. Samples of cell cultures were harvested at time 0 and at $0.5,1,2,4$, $8,16,24$ and $48 \mathrm{~h}$ to measure CD36 expression. Results were obtained by three independent experiments performed in duplicate. The cells were conserved in TriPure Isolation Reagent (Roche Molecular Biochemicals, Mannheim, Germany) at $-80{ }^{\circ} \mathrm{C}$ until the time of RNA and protein isolation. From cultures which were collected at 8,16 and $48 \mathrm{~h}$, protein phases were separated to determinate glycated CD36 and non-glycated CD36.

\section{Experiments in atherosclerotic patients}

A total of 32 patients with documented advanced cardiovascular disease (coronary, cerebrovascular or peripheral) were included in this study. The clinical-epidemiological data of their clinical histories was taken into account. They came from University Regional Hospital from Malaga and were treated surgically by Cardiovascular Surgery Service in 2007 and 2008.

Atherosclerotic patients were subclassified into three groups: patients with type 2 diabetes mellitus (DM), patients with pre-diabetes (preDM) and normoglycemic patients (NG). DM patients were defined as individuals who follow oral antidiabetic treatment and/or insulin treatment and have HbA1c levels over 6.5\%. Subjects without DM were considered preDM if they had HbA1c levels in a range of $5.7-6.4 \%$ and NG if this level was lower than $5.7 \%$ [3].

Patients with severe associated diseases, those in a terminal phase, those with severe mental illness, alcoholism or drug addiction, those under age 18 or over 80 , those with hematological diseases or congenital or acquired immunodeficiency syndrome and those who had been 
treated with immunosuppressant or corticoid drugs during the prior year were excluded.

Clinical and epidemiological data and prescribed treatment at the time of inclusion in the study were obtained from clinical histories. The following parameters were taken into account:

Cardiovascular risk factors including gender, age, diabetes, HTN and tobacco use. Quantitative variables including weight, BMI, total cholesterol, LDL, HDL, triglycerides, glucose, HOMA-IR and HbA1c levels. Treatment with the follow drugs was also considered: antihypertensives, lipid-lowering drugs, oral antidiabetics, insulin and antiaggregants.

The classification of diabetes patients was carried out using the $A D A 2010$ [3] definition according to HbA1c levels, as previously described. In accordance with the Spanish Society of Cardiology's Guidelines on Arterial Hypertension criteria [20], hypertensive individuals were defined as those whose systolic arterial pressure was $\geq 140 \mathrm{mmHg}$ and/or whose diastolic arterial pressure was $\geq 90 \mathrm{mmHg}$, measured on two separate occasions separated by at least two weeks. NCEP-ATPIII 2001 [21] criteria were used in determining hypercholesterolemia. Hypercholesterolemia was defined as values of total cholesterol $\geq 200$ and $\mathrm{LDL} \geq 160 \mathrm{mg} / \mathrm{dL}$ on repeated occasions. Healthy lipid control criteria were defined as an optimal LDL cholesterol level $\leq 100 \mathrm{mg} / \mathrm{dL}$ [21]. Statin use prior to the diagnosis of a cardiac event was also a factor in determining if a subject had hypercholesterolemia. In terms of HDL levels, limits were $\leq 40 \mathrm{mg}$ / $\mathrm{dL}$ in men and $\leq 50 \mathrm{mg} / \mathrm{dL}$ in woman. Hypertriglyceridemia was defined as triglycerides levels $\geq 150 \mathrm{mg} / \mathrm{dL}$ on repeated occasions or being under specific treatment at the time of inclusion [21]. Individuals were considered as obese if they had a body mass index (BMI) above $30 \mathrm{~kg} /$ $\mathrm{m}^{2}$. Patient reporting was used to determine if an individual was a smoker. To be considered an ex-smoker, the patient must have stopped their smoking habit at least 6 months prior to inclusion in the study.

After considering the influence of hyperglycemia on CD36 expression, those patients with fasting glucose levels $\geq 126 \mathrm{mg} / \mathrm{dL}$ during sample collection were also excluded. The final sample size included 22 subjects.

Peripheral blood samples were obtained after subjects fasted and did not take medication for at least $12 \mathrm{~h}$ prior to the phlebotomy. These samples were used to measure biochemical levels and for cell culture. Blood was collected in trisodium citrate $(3.8 \%)$ for use in biochemical testing and in EDTA tubes for cell culture studies. PBMCs were isolated by density gradient centrifugation with Ficoll, as described above, and they were selected according their diameter using a Coulter counter. They were then frozen in TriPure Isolation Reagent $\left(-80^{\circ} \mathrm{C}\right)$ until use.

\section{CD36 receptor expression analysis} CD36 mRNA isolation and quantification

Isolation of CD36 mRNA was performed with TriPure Isolation Reagent (Roche Molecular Biochemicals) following the manufacturer's protocol. RNA purification was carried out using a commercial kit (Qiagen). RNA purity quality was determined according to the $260 / 280$ ratio using a Thermo Scientific NanoDrop 2000. Samples with ratios from 1.7 to 2 were considered suitable for expression studies. $2 \mu \mathrm{g} / \mu \mathrm{L}$ of total RNA was used for reverse transcription to cDNA using a High Capacity cDNA Archive Kit (Applied Biosystems, Carlsbad, CA, USA) in a GeneAmp ${ }^{\circledR}$ PCR System 9700 Thermal Cycler, following the manufacturer's instructions. CD36 cDNA relative quantitation and real-time PCR with the $\Delta \Delta \mathrm{C}_{\mathrm{t}}$ method was performed using TaqMan probes (Hs00169627_m1) with 18S rRNA as an endogenous control gene (Hs99999901-s1). PCRs were carried out with $2 \mu \mathrm{L}$ of cDNA, $25 \mu \mathrm{L}$ of PCR Master Mix (PEBiosystem, Carlsbad, CA, USA) and $2 \mu \mathrm{L}$ of TaqMan probes according to the follow schedule: $95^{\circ} \mathrm{C}, 10 \mathrm{~min}$ (DNA polymerase activation) and 40 cycles at $95^{\circ} \mathrm{C}$ for $15 \mathrm{~s}$ followed by $60{ }^{\circ} \mathrm{C}$ for $1 \mathrm{~min}$, in ABI PRISM 7900 Detection System (Applied Biosystems).

\section{Glycated CD36 and non-glycated CD36 protein isolation and quantification}

Total proteins were isolated using TriPure Isolation Reagent. They were then precipitated with absolute ethanol and washed with guanidine hydrochloride. They were quantified using a BCA Protein Assay Reagent. Protein sample concentration was standardized in order to carry out CD36 quantification using a Western Blot, following the protocol previously described [22]. Total protein separation was carried out under denaturing conditions. Transfer was done using nitrocellulose membranes, commercial iBlot Gel Transfer Stacks and an iBlot Dry Blotting System (IB 1001, Invitrogen) at $23 \mathrm{~V}$ for $7 \mathrm{~min}$. Then, blots were incubated with monoclonal antibodies against human CD36 (ab17044; Abcam; dilution 1:400). Equal protein loading in each line was verified staining filters with Ponceau and also by incubating blots with monoclonal antibodies against B-actin (clone AC-15, Sigma). ChemiDoc (Bio-Rad, Mississauga, ON, Canada) was used to quantify western blot bands using Quantity One 1-D Analysis Software. Results were expressed as arbitrary units (AU) defined as units of intensity $/ \mathrm{mm}^{2}$.

\section{Statistical analysis}

CD36 mRNA expression was used for sample size calculation. Thus, based on a standard deviation of 14.41 (mean value of 51.28) our sample size was calculated to have more than $80 \%$ power to detect a difference of 
approximately $40 \%$ in mRNA expression at $\alpha=0.05$. Following this statistical approach the minimal sample size required was 7 subjects.

The confidence interval was calculated at 95\%. Differences were considered significant if $\mathrm{p}<0.05$. Results were expressed as mean $\pm \mathrm{SD}$. Clinical characteristics of patients were compared using the Mann-Whitney U test. Statistical significance between different groups was calculated using ANOVA. Qualitative variables were compared using Chi square test. The relationship between CD36 and continuous variables was analyzed using the Spearman rank correlation, in which the statistical index to measure a lineal relationship between two quantitative variables was $(-1<\mathrm{r}<1)$. To correct and identify the possible confounding factors in CD36 expression, such as cardiovascular risk factors or drugs, a logistic regression model was used.

Statistical analyses were calculated using SPSS Statistics 20.0 for Windows (IBM Corporation Inc., Somers, NY, USA).

\section{Results}

In vitro experiment

\section{Effects of hyperglycemia on mRNA synthesis}

The results of CD36 mRNA in healthy subjects (Table 1) showed that in the absence of glucose (saline solution) (control group), CD36 expression was stable during the experiment. In cell cultures with NG, there was an increase in mRNA synthesis that measured 2.3 times higher $(0.5 \mathrm{~h})$ than the control group. This difference, however, was not statistically significant. Statistically significant differences between CD36 mRNA in both groups were not observed at other points. However, in HG cell cultures, an increase of CD36 mRNA expression (1.8 times higher than the control group) was detected at $0.5 \mathrm{~h}$, though it was not statistically significant. This was followed by statistically-significant increases at 4 and $24 \mathrm{~h}$, with measurements that were 18.1 and 5.4 times higher, respectively, when compared with the control group.

\section{Effects of hyperglycemia on non-glycated CD36 synthesis}

Table 1 shows non-glycated CD36 protein expression at 8,16 and $48 \mathrm{~h}$. At $8 \mathrm{~h}$, non-glycated CD36 concentration was similar in all groups. However, at $16 \mathrm{~h}$ a maximum peak of protein synthesis was detected in the HG culture, which was 1.6 times higher than that of the control group. At 48 h, CD36 expression in HG returned to basal levels. On the other hand, in the EG cell culture an increase in non-glycated CD36 protein concentration was measured at $48 \mathrm{~h}$ that was 2.1 times higher than that of the control group. In the control group, levels remained stable over the course of the entire experiment.

\section{Effects of hyperglycemia on glycated CD36 synthesis}

Table 1 summarizes glycated CD36 concentration at 8, 16 and $48 \mathrm{~h}$. Glycated CD36 concentrations in the control group were stable over the course of the $48 \mathrm{~h}$. In EG cell culture, lower levels of glycated CD36 concentration were measured in comparison with control group. These levels remained stable until the end of the experiment, although at $48 \mathrm{~h}$, a decrease in CD36 concentration (2.5 times lower than the control group) was detected, which was even lower than the base levels. Glycated CD36 concentration in the HG culture was inhibited during the entire period of the experiment in comparison with the control group.

Table 1 CD36 data at the different time points analyzed in this study

\begin{tabular}{|c|c|c|c|c|c|c|c|c|c|}
\hline \multirow[t]{2}{*}{ Glucose concentration } & \multicolumn{9}{|c|}{ Incubation time } \\
\hline & $\mathrm{Oh}$ & $0.5 \mathrm{~h}$ & $1 \mathrm{~h}$ & $2 \mathrm{~h}$ & $4 \mathrm{~h}$ & $8 \mathrm{~h}$ & $16 \mathrm{~h}$ & $24 \mathrm{~h}$ & $48 \mathrm{~h}$ \\
\hline \multicolumn{10}{|c|}{ Normalized CD36 (CD36 mRNA expression/18s rRNA) } \\
\hline Control: saline (0 mg/dL) & 1.80 & 1.86 & 1.84 & 1.67 & 1.81 & 1.79 & 1.89 & 2.90 & 4.00 \\
\hline EU conditions: 5.5 mM (95 mg/dL) & 1.80 & 4.14 & 0.76 & 1.08 & 1.01 & 2.05 & 3.06 & 4.40 & 7.39 \\
\hline HG conditions: 26 mM (498 mg/dL) & 1.80 & 3.28 & 0.96 & 1.60 & 32.8 & 3.57 & 1.78 & 15.6 & 4.19 \\
\hline \multicolumn{10}{|c|}{ Arbitrary non-glycated CD36 protein concentration levels } \\
\hline Control: saline (0 mg/dL) & - & - & - & - & - & 7.70 & 8.95 & - & 6.37 \\
\hline EU conditions: 5.5 mM (95 mg/dL) & - & - & - & - & - & 7.20 & 8.31 & - & 13.39 \\
\hline HG conditions: 26 mM (498 mg/dL) & - & - & - & - & - & 6.33 & 1.92 & - & 6.65 \\
\hline \multicolumn{10}{|c|}{ Arbitrary glycated CD36 protein concentration levels } \\
\hline Control: saline (0 mg/dL) & - & - & - & - & - & 14.70 & 12.43 & - & 13.99 \\
\hline EU conditions: 5.5 mM (95 mg/dL) & - & - & - & - & - & 10.20 & 11.89 & - & 5.59 \\
\hline HG conditions: 26 mM (498 mg/dL) & - & - & - & - & - & 3.77 & 3.14 & - & 3.17 \\
\hline
\end{tabular}




\section{Results of the experiment on atherosclerotic patients Patient characteristics}

22 atherosclerotic patients were included: 10 DM, 7 preDM and 5 NG (Fig. 1). Table 2 summarizes anthropometric and analytical variables of the 3 groups of atherosclerotic patients. A high prevalence of cardiovascular risk factors was observed in our population. Of 22 patients, 14 had a diagnosis of coronary disease, 3 had significant obstruction of the carotid arteries and 5 had peripheral artery disease. No significant differences were found among the groups in the clinical parameters analyzed with the exception of HbA1c levels $(p=0.02)$. It is important to note that no significant differences were found in fasting blood glucose levels among the three groups. All levels measured were considered NG.

CD36 expression (mRNA and non-glycated and glycated protein levels) in atherosclerotic patients Results of CD36 mRNA in atherosclerotic patients are shown in Fig. 2. mRNA synthesis was higher than in NG patients compared to preDM patients and the level was higher in preDM patients compared to DM patients, although these differences were not statistically significant. Lower levels of non-glycated CD36 protein were found in atherosclerotic patients, though there were no statistically significant differences between the groups (Fig. 2).

Glycated CD36 expression showed a proportional increase that was associated with the level of glucose alteration present in patients. In this sense, in NG patients the mean was $15.9 \pm 8.9$ units, in preDM patients it was $20.4 \pm 6.9$ units and in DM patients it was $31.1 \pm 16.7$ (Fig. 2). Although a statistically significant trend was not observed between the three groups, a significant association was observed when in glycated CD36 protein expression in DM compared to NG patients $(\mathrm{p}=0.03)$.

Multiple regression between CD36 expression ( $m R N A$ and non-glycated and glycated protein levels) and clinical factors Multiple regression analysis was performed to analyze whether CD36 expression was related to the presence of the main clinical factors (gender, age, diabetes, arterial hypertension and smoking habits). Taking glycated CD36 as a dependent variable, the results showed that CD36 expression was related to only diabetes, which was related with glycated CD36 $(\beta=0.46$, $\mathrm{p}=0.03)$. However, in multiple regression analyses which included quantitative variables such as weight, BMI, total cholesterol, LDL, HDL, triglycerides, glucose, insulin, HOMA-IR, and HbA1c, the follow relationships were observed: CD36 mRNA levels were associated with insulin levels $(\beta=-0.59, \mathrm{p}=0.02)$; non-glycated CD36 was associated with BMI $(\beta=0.72, \mathrm{p}=0.001)$ and glycated CD36 was associated with weight $(\beta=0.71$, $\mathrm{p}=0.001)$.

All treatments (antihypertensives, lipid-lowering drugs, oral antidiabetics, insulin and antiaggregants) were taken into account when conducting the analyses, but only metformin was related with glycated and non-glycated

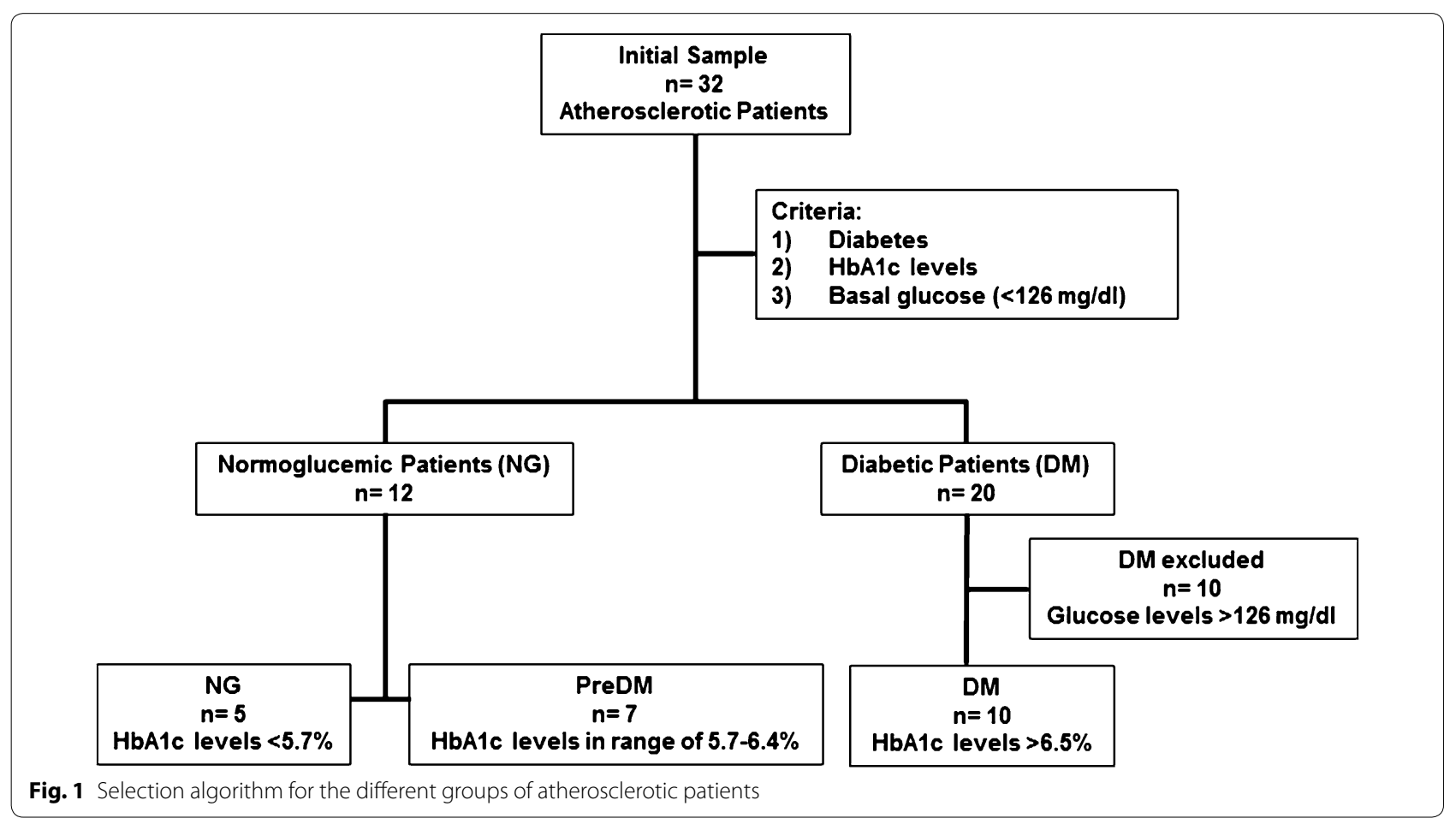


Table 2 Anthropometric and analytic variables and treatment of the atherosclerotic patients groups

\begin{tabular}{|c|c|c|c|c|}
\hline Variable & NG & Pre DM & DM & $p$ value \\
\hline \multicolumn{5}{|c|}{ Anthropometric and analytical variables } \\
\hline $\mathrm{N}$ & 5 & 7 & 10 & 0.4 \\
\hline Age (years) & $59 \pm 11$ & $66 \pm 14$ & $61 \pm 8$ & 0.5 \\
\hline Weight (Kg) & $76.1 \pm 13.7$ & $71.8 \pm 13.4$ & $91.6 \pm 24.8$ & 0.1 \\
\hline BMI $\left(\mathrm{Kg} / \mathrm{m}^{2}\right)$ & $27.5 \pm 3.8$ & $26.3 \pm 4.1$ & $33 \pm 3.4$ & 0.2 \\
\hline $\mathrm{SBP}(\mathrm{mm} \mathrm{Hg})$ & $131 \pm 21$ & $139 \pm 18$ & $121 \pm 23$ & 0.3 \\
\hline $\mathrm{DBP}(\mathrm{mm} \mathrm{Hg})$ & $73 \pm 15$ & $81 \pm 16$ & $68 \pm 9$ & 0.2 \\
\hline $\begin{array}{l}\text { Glucose (mg/ } \\
\text { dL) }\end{array}$ & $94 \pm 5$ & $97 \pm 11$ & $101 \pm 11$ & 0.4 \\
\hline $\begin{array}{l}\text { Total choles- } \\
\text { terol (mg/ } \\
\text { dL) }\end{array}$ & $153 \pm 53$ & $158 \pm 38$ & $138 \pm 47$ & 0.7 \\
\hline $\begin{array}{l}\mathrm{LDL}-\mathrm{C}(\mathrm{mg} / \\
\mathrm{dL})\end{array}$ & $96 \pm 40$ & $106 \pm 27$ & $71 \pm 30$ & 0.1 \\
\hline $\begin{array}{l}\mathrm{HDL}-\mathrm{C}(\mathrm{mg} / \\
\mathrm{dL})\end{array}$ & $32 \pm 7$ & $28 \pm 10$ & $41 \pm 22$ & 0.3 \\
\hline $\begin{array}{l}\text { Triglycerides } \\
\text { (mg/dL) }\end{array}$ & 119 (95-189) & $135(112-170)$ & $122(100-183)$ & 1.0 \\
\hline $\mathrm{HbA1c}(\%)$ & $5.3 \pm 0.3$ & $5.9 \pm 0.2$ & $6.5 \pm 1.0$ & 0.02 \\
\hline $\begin{array}{l}\text { Insulin }(\mu \mathrm{U} / \\
\mathrm{mL})\end{array}$ & $14.2 \pm 2.5$ & $11.3 \pm 6.0$ & $13.2 \pm 7.6$ & 0.8 \\
\hline HOMA index & $3.3 \pm 0.6$ & $2.8 \pm 1.7$ & $3.3 \pm 2.1$ & 0.9 \\
\hline \multicolumn{5}{|c|}{ Cardiovascular risk factors } \\
\hline $\begin{array}{l}\text { Gender (\% } \\
\text { males) }\end{array}$ & 80 & 57 & 80 & 0.5 \\
\hline $\begin{array}{l}\text { Arterial hyper- } \\
\text { tension (\%) }\end{array}$ & 80 & 57 & 100 & 0.1 \\
\hline $\begin{array}{l}\text { Dyslipidemia } \\
\text { (\%) }\end{array}$ & 80 & 57 & 60 & 0.7 \\
\hline $\begin{array}{l}\text { Smoking } \\
\text { habits (\%) }\end{array}$ & 60 & 29 & 10 & 0.1 \\
\hline Ex-smokers & 40 & 14 & 20 & \\
\hline $\begin{array}{l}\text { Non-smok- } \\
\text { ers }\end{array}$ & 0 & 57 & 70 & \\
\hline Obesity (\%) & 60 & 29 & 70 & 0.2 \\
\hline Overweight & 20 & 43 & 20 & \\
\hline $\begin{array}{l}\text { Normal } \\
\text { weight }\end{array}$ & 20 & 28 & 10 & \\
\hline \multicolumn{5}{|l|}{ Treatment N (\%) } \\
\hline $\begin{array}{l}\text { Oral anti- } \\
\text { diabetics } \\
\text { (ADO) }\end{array}$ & $0(0 \%)$ & $0(0 \%)$ & $8(80 \%)$ & \\
\hline Metformin & $0(0 \%)$ & $0(0 \%)$ & $7(70 \%)$ & \\
\hline $\begin{array}{l}\text { Sulfonylu- } \\
\text { reas }\end{array}$ & $0(0 \%)$ & $0(0 \%)$ & $3(30 \%)$ & \\
\hline Insulin & $0(0 \%)$ & $0(0 \%)$ & $4(40 \%)$ & \\
\hline $\begin{array}{l}\text { Lipid-lower- } \\
\text { ing drugs }\end{array}$ & $2(40 \%)$ & $3(42.9 \%)$ & $8(80 \%)$ & 0.1 \\
\hline Statins & $2(40 \%)$ & $3(42.9 \%)$ & $8(80 \%)$ & 0.1 \\
\hline $\begin{array}{l}\text { Antihyperten- } \\
\text { sives }\end{array}$ & $4(80 \%)$ & $4(57.1 \%)$ & $10(100 \%)$ & 0.1 \\
\hline $\begin{array}{l}\text { ACE inhibi- } \\
\text { tors }\end{array}$ & $2(40 \%)$ & $1(14.3 \%)$ & $4(40 \%)$ & 0.4 \\
\hline
\end{tabular}

Table 2 continued

\begin{tabular}{lllll}
\hline Variable & NG & Pre DM & DM & p value \\
\hline ARBs & $0(0 \%)$ & $1(14.3 \%)$ & $5(50 \%)$ & 0.1 \\
$\begin{array}{c}\text { Beta block- } \\
\text { ers }\end{array}$ & $1(20 \%)$ & $3(42.9 \%)$ & $4(40 \%)$ & 0.4 \\
$\begin{array}{l}\text { Antiag- } \\
\text { gregants }\end{array}$ & $3(60 \%)$ & $5(71.4 \%)$ & $9(90 \%)$ & 0.2 \\
ASA & $2(40 \%)$ & $4(57.1 \%)$ & $9(90 \%)$ & 0.1 \\
Clopidogrel & $1(20 \%)$ & $1(14.3 \%)$ & $0(0 \%)$ & 1.0
\end{tabular}

Data shown as mean \pm SD

CD36 protein expression $[(\beta=0.47, p=0.03),(\beta=0.61$, $\mathrm{p}=0.003)$ respectively)].

\section{Discussion}

Atherosclerosis has become one of the most important public health issues in recent decades. This pathology is especially severe among diabetic patients. With the objective of analyzing the influence of glucose metabolism on the atherogenic process, our study focused on the scavenger receptor CD36 in peripheral cells (monocytes), which is a key element in the formation of atheromas. We have found that hyperglycemic conditions have been shown to be responsible for the increase in CD36 (mRNA and nonglycated protein) synthesis in healthy subjects. However, this condition can inhibit glycated CD36 protein expression, as has been found in patients with poorly-controlled diabetes in another study carried out by our group [17]. On the other hand, in atherosclerotic patients, progressive (both, mRNA and glycated) CD36 overexpression has been detected in preDM y DM individuals and is attributed to a post-translational stimulus related with the hyperglycemic state of these patients, a concept which has been previously proposed by other authors [23].

Hyperglycemia has been described as an important stimulator of in vitro CD36 expression, both on the mRNA [24] and protein levels [23-26]. Our results are in agreement with some of these studies which have indicated that hyperglycemia is a stimulus of mRNA synthesis. This effect seems to fluctuate as time passes (Fig. 1), which would explain the different results obtained by other authors $[24,27]$. In our study, it has been detected that glucose can influence the de novo synthesis of non-glycated CD36 proteins, which appeared sooner and in higher levels when the glucose concentration was higher; this effect, however, seemed to be limited by time. Higher glucose concentration also inhibited glycated CD36 expression in healthy subjects, as has been reported [27], though other authors have found contrary results [23, 25]. Inhibition was shown since the beginning of the study and was not as important in monocytes cultured in lower glucose levels (EG conditions), which later showed a decrease in glycated CD36 


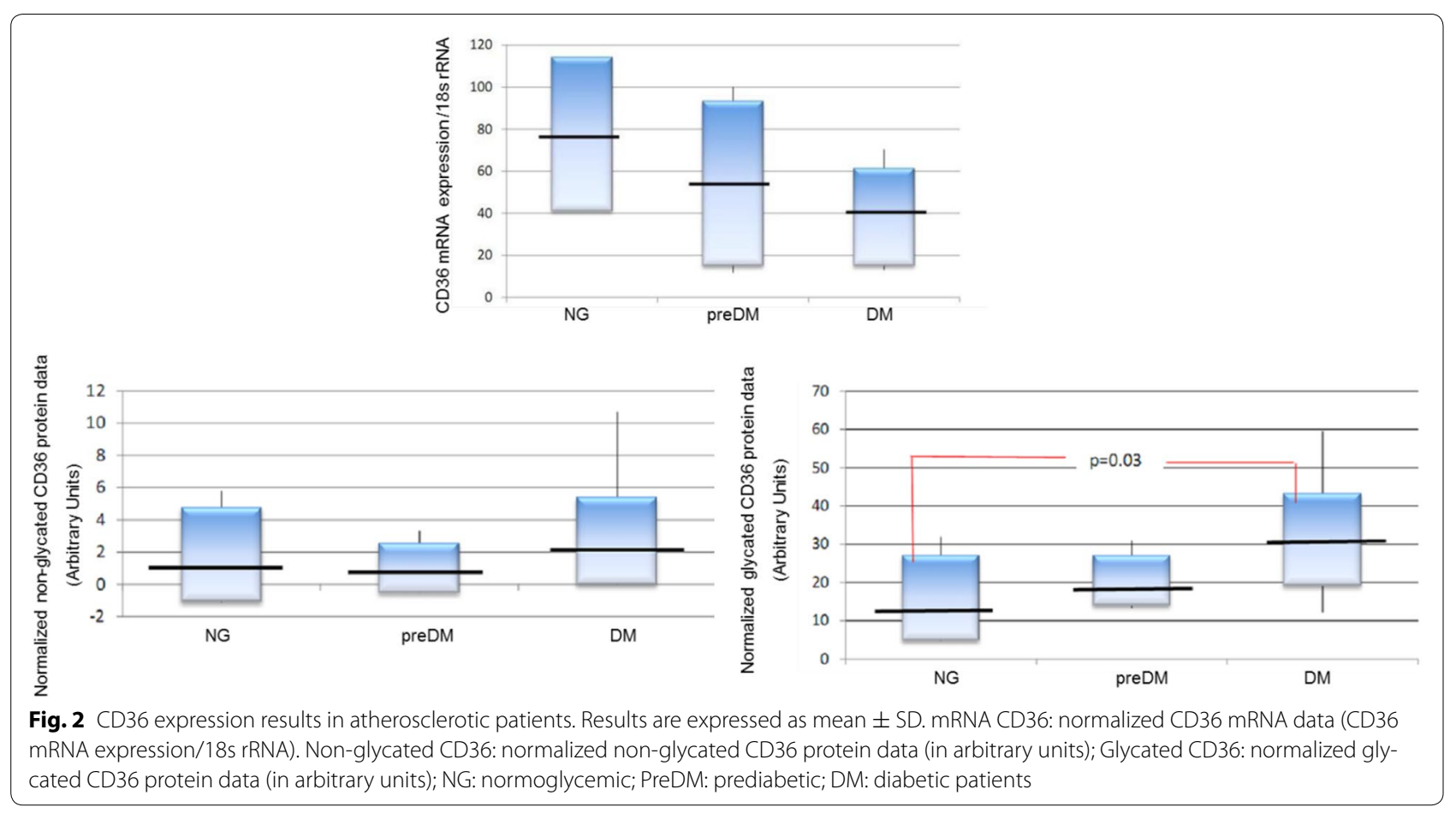

protein expression. These results indicate that expression inhibition is directly related with glucose concentration. The results of this study have shown that hyperglycemia is a powerful inhibitor of glycated CD36. These results are in agreement with other studies previously published by our group [17]. As such, in order to avoid interference in the analyses carried out in our study, we eliminated all individuals whose illness was poorly controlled, defined as those who had glucose levels that were higher than $126 \mathrm{mg} / \mathrm{dL}$ at the time of blood extraction from the study, before starting with the experiments.

The impact of acute hyperglycemia on atherosclerosis is not clear. Among the effects described are plasma lipoprotein alterations, an increase in free radicals and an increase in leukocyte adhesion molecules as a consequence of the increase in blood glucose levels. Some of these factors, such as IL-4 or oxLDL, are responsible for regulation of CD36 expression [28, 29]. In our study, atherosclerotic patients were not shown to have statistically significant differences in mRNA levels among the different groups, but results indicated an inverse relationship between glucose metabolism alteration and CD36 mRNA synthesis (Fig. 2). Moreover, differences in nonglycated CD36 levels between the patients groups were not observed (Fig. 2). Although it has been stated that glucose can regulate CD36 protein/mRNA? expression at the translational level [23], in our study, lower nonglycated protein levels indicated that mRNA translation to proteins was regulated independently from glucose metabolism alteration. Furthermore, atherosclerotic patients showed differences in glycosylated CD36 protein expression in DM, preDM and NG states, with statistically significant differences observed when comparing DM and NG patients (Fig. 2). This indicates that alterations in glucose metabolism can increase glycosylated CD36 protein expression by increasing post-translational modifications. Currently, there is controversy regarding the influence of glucose control in diabetic patients and CD36 mRNA/glycated/non-glycated?? expression [30]. It is thought that the difference in patients' degrees of atherosclerosis could explain the differences in the results. Moreover, glucose control could affect CD36 expression in poorly-controlled atherosclerotic subjects, inducing increased expression of CD36 in these patients [16]. On the contrary, in diabetic patients without atherosclerotic disease, it was found that CD36 mRNA/ glycated/non-glycated?? expression rates were higher in well-controlled patients [30]. In our study, all patients' glucose levels were very well-controlled, with a mean HbA1c of $6.5 \pm 1.0 \%$. As such, we hypothesize that additional mechanisms could play a role. Taking into account our results (mRNA, non-glycated and glycated proteins in NG, preDM and DM patients), we believe that in diabetic patients, there could be a higher concentration of CD36 in cytoplasmic granules that would be quickly mobilized under hyperglycemic conditions, as has been proposed by other authors [30]. In this sense, our results suggest that higher levels of CD36 mRNA/glycated/ 
non-glycated?? expression are due to an increase in recycling, because non-glycated CD36 was stable for the duration of the study in the three patient groups, mRNA levels were lower in NG patients compared with preDM patients and both groups had lower mRNA levels with respect to DM patients. Nevertheless, we cannot discount the possibility of other factors such as increased efficiency in post-translational changes, especially glycosylation, as a response to glucose metabolism alteration, as has been propose by other authors.

Current type 2 diabetes diagnostic criteria include a cutpoint beyond which hyperglycemia is associated with the development of microvascular lesions, especially retinopathy [3]. However, atherosclerotic macrovascular disease occurs in the prediabetic stages [31]. In our study, we have analyzed preDM patients with an overexpression of CD36 as compared with NG and we hypothesize that this mechanism could be involved in the early atherogenesis observed in prediabetic stages.

CD36 is a key element in the relationship between atherosclerosis and glucose metabolism, as it has multiple ligands and it is present in some tissues where this receptor acts as mediator in this process. On the one hand, CD36 mRNA/glycated/non-glycated?? expression has been related to atherosclerotic development in the general and the diabetic population [30, 32, 33]. CD36 levels correlate with development of diabetic microvascular complications, especially nephropathy $[34,35]$. On the other hand, it has been demonstrated that soluble CD36 in plasma is an insulin-resistance marker [33, 36]. At the adipocyte level, oxLDL uptake by the receptor causes the appearance of insulin-resistance [37] by means of the interaction of multiple CD36 ligands with the serine/threonine kinase system that regulates the ligand-dependent signaling of the insulin receptor [38]. Moreover, CD36 has been related with the inflammatory response present in obesity and metabolic syndrome [39]. However, it is not clear if the higher CD36 mRNA/glycated/non-glycated?? expression found in DM patients is exclusively due to insulin resistance. Published data are contradictory on the effect of CD36 on the development of insulin resistance. Some studies have been carried out on segments of the Japanese population with a congenital CD36 deficit which have shown that this deficit could be both a risk factor and a protective factor in the development of insulin resistance $[40,41]$ and it has been suggested that this discordance could be due to the presence of pathological molecule development, such as oxLDL in a pro-inflammatory environment [42]. Insulin has the capacity to act on immune cells, increasing CD36 mRNA/glycated/non-glycated? expression and increasing the capacity for oxLDL molecule uptake [43]; in our results, an inverse relationship with CD36 mRNA levels has been observed.
Other authors have postulated that CD36 mRNA/ glycated/non-glycated?? overexpression in the insulinresistance stages could be related to certain characteristics of obesity. Along these lines, we have found a relationship between both glycated CD36 expression and weight and non-glycated CD36 and BMI. This data could indicate that obesity would be a post-translational stimulus for CD36 mRNA/glycated/non-glycated?? expression. In another study carried out by our group, it was found that levels of glycated CD36 were significantly higher in patients with 3 or 4 atherosclerotic risk factors than in patients with a lower number of risk factors in subjects with no atherosclerotic symptoms [17]. That study described the importance of weight as an atherosclerotic risk factor.

CD36 expression in patients in this study has also been shown to be related with the use of metformin. This drug increased glycated and non-glycated CD36 expression $[(\beta=0.47, p=0.03)$ and $(\beta=0.61, p=0.003)$, respectively]. Our results differ from previously published data, where metformin has been shown to have the capacity to decrease in vitro CD36 mRNA/glycated/non-glycated?? expression in skeletal muscle cells [44, 45] and macrophages, [46] but not in adipocytes [47].

In our study, an increase of CD36 mRNA and nonglycated expression in HG conditions in healthy subjects has been observed. This is a process which oscillates over time. However, upon analysis, differences exist in glycated proteins, which are inhibited by HG conditions. On the other hand, glycated CD36 expression is higher in DM patients compare to preDM. The results show a possible correlation between glycated CD36 levels and alterations in glucose metabolism. However, these differences were not statistically significant, though this may be due to the limited number of subjects. A larger sample size will helps us to corroborate these results and determine if there is a relationship between mRNA and preDM or DM development.

In summary, our results have shown that hyperglycemic conditions increase glycated/non-glycated expression. This overexpression appears in prediabetic stages and can induce the early development of atherosclerosis in those with subdiabetic levels of hyperglycemia.

\section{Authors' contributions}

MDLC contributed to analysis and interpretation of data and drafting the article. MCPS contributed to review the manuscript, revising it critically for important intellectual content and final approval of the version to be published. AVC contributed to acquisition of data analysis. FJT contributed to conception and design. RGH contributed to conception and design, analysis and interpretation of data, drafting the article, reviewing it, revising it critically for important intellectual content and final approval of the version to be published. MRBL contributed to conception and design, analysis and interpretation of data, drafting the article, reviewing it, revising it critically for important intellectual content and final approval of the version to be published. All authors read and approved the final manuscript. 


\begin{abstract}
Author details
${ }^{1}$ Internal Medicine Department, Biomedical Institute of Malaga (IBIMA), Regional University Hospital of Malaga (Carlos Haya Hospital), Avda. Hospital Civil s/n, 29009 Malaga, Spain. ${ }^{2}$ Research Laboratory-Allergy Unit, Biomedical Institute of Malaga (IBIMA), Regional University Hospital of Malaga (Carlos Haya Hospital), Malaga, Spain. ${ }^{3}$ Endocrinology and Nutrition Department, Biomedical Institute of Malaga (IBIMA), Regional University Hospital of Malaga (Virgen de la Victoria Hospital), Malaga, Spain. ${ }^{4}$ CIBERFisiopatología de la Obesidad y Nutrición, Instituto de Salud Carlos III, Madrid, Spain.
\end{abstract}

\section{Acknowledgements}

We thank Tatiana Diaz-Cordoba and Inmaculada Martin-Martin for their excellent laboratory assistance in the Malaga Hospital-IBIMA Biobank and Claire Alexandra Conrad for her help with the final English-language version.

\section{Competing interests}

The authors declare that they have no competing interests.

\section{Availability of data and materials}

The data and material can be solicited to the corresponding author.

\section{Ethics statement}

The study protocol complied with the principles of the Declaration of Helsinki. This study was approved by the ethics committees of the different participating institutions (Andalusian Biomedical Research Ethics Coordinating Committee). Additionally, the reporting of the study is in accordance with the Strengthening the Reporting of Observational Studies in Epidemiology (STROBE) statement as well as the broader Enhancing of the Quality and Transparency of Health Research (EQUATOR) guidelines [48]. All participating individuals included were selected independently of their sex or gender. All were informed and signed an informed consent form.

\section{Funding}

This work was supported by grants from the Instituto de Salud Carlos III, cofinanced by the Fondo Europeo de Desarrollo Regional-FEDER [FIS PI14/00696, PI12/01373 and "Centros de Investigación En Red" (CIBER, CB06/03/0018)]. M. Rosa Bernal-Lopez was supported by "Miguel Servet Type I" program (CP15/00028) from the ISCIII, Madrid (Spain).

\section{Publisher's Note}

Springer Nature remains neutral with regard to jurisdictional claims in published maps and institutional affiliations.

Received: 27 October 2016 Accepted: 12 July 2017 Published online: 18 July 2017

\section{References}

1. Cooper R, Cutler J, Desvigne-Nickens P, Fortmann SP, Friedman L, Havlik R, et al. Trends and disparities in coronary heart disease, stroke, and other cardiovascular diseases in the United States: findings of the national conference on cardiovascular disease prevention. Circulation. 2000;102(25):3137-47.

2. Ford ES. Trends in predicted 10-year risk of coronary heart disease and cardiovascular disease among US adults from 1999 to 2010. J Am Coll Cardiol. 2013;61(22):2249-52.

3. Executive summary. Standards of medical care in diabetes-2010. Diabetes Care. 2010;33(Suppl1):S4-10.

4. Park YM, Kashyap SR, Major JA, Silverstein RL. Insulin promotes macrophage foam cell formation: potential implications in diabetes-related atherosclerosis. Lab Invest. 2012;92(8):1171-80.

5. The DECODE study group, European Diabetes Epidemiology Group. Glucose tolerance and mortality: comparison of WHO and American Diabetes Association diagnostic criteria. Diabetes epidemiology: Collaborative analysis Of Diagnostic criteria in Europe. Lancet. 1999;354(9179):617-21.

6. Vollmer E, Brust J, Roessner A, Bosse A, Burwikel F, Kaesberg B, et al. Distribution patterns of apolipoproteins $A 1, A 2$, and $B$ in the wall of atherosclerotic vessels. Virchows Arch A Pathol Anat Histopathol. 1991;419(2):79-88.
7. Schwenke DC, Carew TE. Initiation of atherosclerotic lesions in cholesterolfed rabbits. II. Selective retention of LDL vs. selective increases in LDL permeability in susceptible sites of arteries. Arteriosclerosis. 1989;9(6):908-18.

8. Schwenke DC, Carew TE. Initiation of atherosclerotic lesions in cholesterol-fed rabbits. I. Focal increases in arterial LDL concentration precede development of fatty streak lesions. Arteriosclerosis. 1989;9(6):895-907.

9. Pitas RE. Expression of the acetyl low density lipoprotein receptor by rabbit fibroblasts and smooth muscle cells. Up-regulation by phorbol esters. J Biol Chem. 1990;265(21):12722-7.

10. Goldstein JL, Brown MS. The low-density lipoprotein pathway and its relation to atherosclerosis. Annu Rev Biochem. 1977;46:897-930.

11. Goldstein JL, Brown MS. Atherosclerosis and its complications: contributions from the Association of American Physicians, 1886-1986. Trans Assoc Am Phys. 1986;99:ccxxxi-ccxlvii.

12. Aguilar-Gaytan R, Mas-Oliva J. The scavenger receptor and its importance in amyloid processes. Gac Med Mex. 2002;138(5):445-60.

13. Kunjathoor W, Febbraio M, Podrez EA, Moore KJ, Andersson L, Koehn S, et al. Scavenger receptors class A-I/II and CD36 are the principal receptors responsible for the uptake of modified low density lipoprotein leading to lipid loading in macrophages. J Biol Chem. 2002;277(51):49982-8.

14. Podrez EA, Febbraio M, Sheibani N, Schmitt D, Silverstein RL, Hajjar DP, et al. Macrophage scavenger receptor CD36 is the major receptor for LDL modified by monocyte-generated reactive nitrogen species. J Clin Invest. 2000;105(8):1095-108.

15. Febbraio M, Podrez EA, Smith JD, Hajjar DP, Hazen SL, Hoff HF, et al. Targeted disruption of the class B scavenger receptor CD36 protects against atherosclerotic lesion development in mice. J Clin Invest. 2000;105(8):1049-56.

16. Zhang HM, Zhang XL, Zhou X, Li D, Gu JG, Wu JJ. Mechanism linking atherosclerosis and type 2 diabetes: increased expression of scavenger receptor CD36 in monocytes. Chin Med J (Engl). 2005;118(20):1717-22.

17. Bernal-Lopez MR, Llorente-Cortes V, Lopez-Carmona D, Mayas DM, Gomez-Huelgas R, Tinahones FJ, et al. Modulation of human monocyte CD36 by type 2 diabetes mellitus and other atherosclerotic risk factors. Eur J Clin Invest. 2011;41(8):854-62.

18. Syed Ikmal SI, Zaman Huri H, Vethakkan SR, Wan Ahmad WA. Potential biomarkers of insulin resistance and atherosclerosis in type 2 diabetes mellitus patients with coronary artery disease. Int J Endocrinol. 2013;2013:698567.

19. Ramos-Arellano LE, Munoz-Valle JF, De la Cruz-Mosso U, Salgado-Bernabe AB, Castro-Alarcon N, Parra-Rojas I. Circulating CD36 and oxLDL levels are associated with cardiovascular risk factors in young subjects. BMC Cardiovasc Disord. 2014;14:54.

20. Lombera Romero F, Barrios Alonso V, Soria Arcos F, Placer Peralta L, Cruz Fernandez JM, Tomas Abadal L, et al. Spanish society of cardiology practice guidelines on arterial hypertension. Rev Esp Cardiol. 2000;53(1):66-90.

21. Lepor NE, Vogel RE. Summary of the third report of the National Cholesterol Education Program Adult Treatment Panel III. Rev Cardiovasc Med. 2001;2(3):160-5.

22. Llorente-Cortes V, Royo T, Otero-Vinas M, Berrozpe M, Badimon L. Sterol regulatory element binding proteins downregulate $L D L$ receptor-related protein (LRP1) expression and LRP1-mediated aggregated LDL uptake by human macrophages. Cardiovasc Res. 2007;74(3):526-36.

23. Griffin E, Re A, Hamel N, Fu C, Bush H, McCaffrey T, et al. A link between diabetes and atherosclerosis: glucose regulates expression of CD36 at the level of translation. Nat Med. 2001;7(7):840-6.

24. Huh HY, Pearce SF, Yesner LM, Schindler JL, Silverstein RL. Regulated expression of CD36 during monocyte-to-macrophage differentiation: potential role of CD36 in foam cell formation. Blood. 1996;87(5):2020-8.

25. Koliakos G, Zolota Z, Paletas K, Kaloyianni M. High glucose concentrations stimulate human monocyte sodium/hydrogen exchanger activity and modulate atherosclerosis-related functions. Pflugers Arch. 2004;449(3):298-306.

26. Lu H, Yao K, Huang D, Sun A, Zou Y, Qian J, et al. High glucose induces upregulation of scavenger receptors and promotes maturation of dendritic cells. Cardiovasc Diabetol. 2013;12:80.

27. Moheimani F, Tan JT, Brown BE, Heather AK, van Reyk DM, Davies MJ. Effect of exposure of human monocyte-derived macrophages to high, versus normal, glucose on subsequent lipid accumulation from glycated and acetylated low-density lipoproteins. Exp Diabetes Res. 2011;2011:851280. 
28. Feng J, Han J, Pearce SF, Silverstein RL, Gotto AM Jr, Hajjar DP, et al. Induction of CD36 expression by oxidized LDL and IL-4 by a common signaling pathway dependent on protein kinase C and PPAR-gamma. J Lipid Res. 2000;41(5):688-96.

29. Nagy L, Tontonoz P, Alvarez JG, Chen H, Evans RM. Oxidized LDL regulates macrophage gene expression through ligand activation of PPARgamma. Cell. 1998;93(2):229-40.

30. Sampson MJ, Davies IR, Braschi S, Ivory K, Hughes DA. Increased expression of a scavenger receptor (CD36) in monocytes from subjects with Type 2 diabetes. Atherosclerosis. 2003;167(1):129-34.

31. Ford ES, Zhao G, Li C. Pre-diabetes and the risk for cardiovascular disease: a systematic review of the evidence. J Am Coll Cardiol. 2010;55(13):1310-7.

32. Handberg A, Levin K, Hojlund K, Beck-Nielsen H. Identification of the oxidized low-density lipoprotein scavenger receptor CD36 in plasma: a novel marker of insulin resistance. Circulation. 2006;114(11):1169-76.

33. Handberg A, Hojlund K, Gastaldelli A, Flyvbjerg A, Dekker JM, Petrie J, et al. Plasma sCD36 is associated with markers of atherosclerosis, insulin resistance and fatty liver in a nondiabetic healthy population. J Intern Med. 2012;271(3):294-304.

34. Susztak K, Ciccone E, McCue P, Sharma K, Bottinger EP. Multiple metabolic hits converge on CD36 as novel mediator of tubular epithelial apoptosis in diabetic nephropathy. PLoS Med. 2005;2(2):e45.

35. Eibl N, Krugluger W, Streit G, Schrattbauer K, Hopmeier P, Schernthaner G. Improved metabolic control decreases platelet activation markers in patients with type-2 diabetes. Eur J Clin Invest. 2004;34(3):205-9.

36. Glintborg D, Hojlund K, Andersen M, Henriksen JE, Beck-Nielsen H, Handberg A. Soluble CD36 and risk markers of insulin resistance and atherosclerosis are elevated in polycystic ovary syndrome and significantly reduced during pioglitazone treatment. Diabetes Care. 2008;31(2):328-34.

37. Kashyap SR, loachimescu AG, Gornik HL, Gopan T, Davidson MB, Makdissi $A$, et al. Lipid-induced insulin resistance is associated with increased monocyte expression of scavenger receptor CD36 and internalization of oxidized LDL. Obesity (Silver Spring). 2009;17(12):2142-8.
38. Morino K, Petersen KF, Shulman Gl. Molecular mechanisms of insulin resistance in humans and their potential links with mitochondrial dysfunction. Diabetes. 2006;55(Suppl 2):S9-15.

39. Silverstein RL, Febbraio M. CD36, a scavenger receptor involved in immunity, metabolism, angiogenesis, and behavior. Sci Signal. 2009;2(72):re3.

40. Furuhashi M, Ura N, Nakata T, Tanaka T, Shimamoto K. Genotype in human CD36 deficiency and diabetes mellitus. Diabet Med. 2004;21(8):952-3.

41. Kuwasako T, Hirano K, Sakai N, Ishigami M, Hiraoka H, Yakub MJ, et al. Lipoprotein abnormalities in human genetic CD36 deficiency associated with insulin resistance and abnormal fatty acid metabolism. Diabetes Care. 2003;26(5):1647-8

42. Kennedy DJ, Kuchibhotla S, Westfall KM, Silverstein RL, Morton RE, Febbraio M. A CD36-dependent pathway enhances macrophage and adipose tissue inflammation and impairs insulin signalling. Cardiovasc Res. 2011;89(3):604-13.

43. Lu H, Huang D, Yao K, Li C, Chang S, Dai Y, et al. Insulin enhances dendritic cell maturation and scavenger receptor-mediated uptake of oxidised low-density lipoprotein. J Diabetes Complicat. 2015;29(4):465-71.

44. Smith AC, Mullen KL, Junkin KA, Nickerson J, Chabowski A, Bonen A, et al. Metformin and exercise reduce muscle FAT/CD36 and lipid accumulation and blunt the progression of high-fat diet-induced hyperglycemia. Am J Physiol Endocrinol Metab. 2007;293(1):E172-81.

45. Bogachus LD, Turcotte LP. Genetic downregulation of AMPK-alpha isoforms uncovers the mechanism by which metformin decreases FA uptake and oxidation in skeletal muscle cells. Am J Physiol Cell Physiol. 2010;299(6):C1549-61.

46. Hyun B, Shin S, Lee A, Lee S, Song Y, Ha NJ, et al. Metformin downregulates TNF-alpha secretion via suppression of scavenger receptors in macrophages. Immune Netw. 2013;13(4):123-32.

47. Rasouli N, Yao-Borengasser A, Varma V, Spencer HJ, McGehee RE Jr, Peterson CA, et al. Association of scavenger receptors in adipose tissue with insulin resistance in nondiabetic humans. Arterioscler Thromb Vasc Biol. 2009;29(9):1328-35.

48. Simera I, Moher D, Hoey J, Schulz KF, Altman DG. A catalogue of reporting guidelines for health research. Eur J Clin Invest. 2010;40(1):35-53.

\section{Submit your next manuscript to BioMed Central and we will help you at every step:}

- We accept pre-submission inquiries

- Our selector tool helps you to find the most relevant journal

- We provide round the clock customer support

- Convenient online submission

- Thorough peer review

- Inclusion in PubMed and all major indexing services

- Maximum visibility for your research

Submit your manuscript at www.biomedcentral.com/submit
() Biomed Central 